\title{
Clinical and epidemiological teaching of dengue through simulated practice
}

\author{
Ensino clínico e epidemiológico de dengue por meio da prática simulada \\ Enseñanza clínica y epidemiológica de dengue por medio de la práctica simulada
}

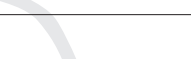

João Henrique de Morais Ribeiro', Eloá Otrenti", Renata Ferreira Takahashi", Lúcia Yasuko Izumi Nichiata", Maria Clara Padoveze", Érica Gomes Pereira", Sebastião Silveira Nunes Júnior'I", Anna Luiza de Fátima Pinho Lins Gryschek", Suely Itsuko Ciosak'

' Universidade de São Paulo, School of Nursing of Ribeirão Preto, Interunit Program for PhD in Nursing. Ribeirão Preto, São Paulo, Brazil.

"Universidade de São Paulo, School of Nursing, Department of Nursing in Collective Health. São Paulo, Brazil.

II' Universidade de São Paulo, Postgraduate Program in Nursing. São Paulo, Brazil.
\end{abstract}

\begin{abstract}
How to cite this article:
Ribeiro JHM, Otrenti E, Takahashi RF, Nichiata LYI, Padoveze MC, Pereira EG, et al. Clinical and epidemiological teaching of dengue through simulated practice. Rev Bras Enferm [Internet]. 2017;70(5):451-6.
\end{abstract}

DOI: http://dx.doi.org/10.1590/0034-7167-2016-0503

Submission: 10-19-2016 Approval: 02-06-2017

\section{ABSTRACT}

Objective: to describe the experience of clinical teaching on dengue and the practice of epidemiological surveillance using problematization methodology. Method: report of experience on educational activity with undergraduate nursing students, held in March 2016, at a public university in the city of São Paulo, conceived in four stages: dialogic lecture, active search of Aedes aegypti, case study and simulation of nursing consultation to individuals with dengue. Results: The activity allowed to retrieve previous knowledge about the disease, respond to exercises that addressed different clinical situations and epidemiological surveillance, including in situ evaluation of possible mosquito outbreaks, and discuss the need to expand prevention and health of the individual and the community, the impact of the media in the dissemination of cases and the coping difficulties experienced in the different levels of attention. Conclusion: the methodology adopted enabled qualified training of students to cope with dengue.

Descriptors: Problem-Based Learning; Dengue; Nursing; Collective Health; Communicable Diseases.

\section{RESUMO}

Objetivo: descrever a experiência de ensino clínico sobre a dengue e a prática de vigilância epidemiológica utilizando metodologia da problematização. Método: relato de experiência sobre atividade educativa com graduandos de Enfermagem, realizada em março de 2016, em uma universidade pública da cidade de São Paulo, concebida em quatro etapas: aula expositiva dialogada, busca ativa do Aedes aegypti, estudo de caso e simulação de consulta de enfermagem a indivíduos com dengue. Resultados: A atividade permitiu resgatar conhecimentos prévios sobre a doença, responder a exercícios que abordavam distintas situações clínicas e de vigilância epidemiológica, incluindo avaliação "in loco" de possíveis focos do mosquito, e discutir a necessidade de ampliação das ações de prevenção e promoção da saúde do indivíduo e coletividade, o impacto da mídia na divulgação dos casos e as dificuldades de enfrentamento vivenciadas nos diferentes níveis de atenção. Conclusão: a metodologia adotada possibilitou capacitação qualificada dos alunos para enfrentamento da dengue.

Descritores: Aprendizagem Baseada em Problemas; Dengue; Enfermagem; Saúde Coletiva; Doenças Transmissíveis.

\section{RESUMEN}

Objetivo: describir la experiencia de enseñanza clínica sobre la dengue y la práctica de vigilancia epidemiológica utilizando metodología de la problematización. Método: relato de experiencia sobre actividad educativa con graduandos de Enfermería, realizada en marzo de 2016, en una universidad pública de la ciudad de São Paulo, concebida en cuatro etapas: clase expositiva dialogada, busca activa del Aedes aegypti, estudio de caso y simulación de consulta de enfermería a individuos con dengue. Resultados: La actividad permitió rescatar conocimientos previos sobre la enfermedad, responder a ejercicios que abordaban distintas situaciones clínicas y de vigilancia epidemiológica, incluyendo evaluación "in loco" de posibles focos del mosquito, y discutir la necesidad de ampliación de las acciones de prevención y promoción de la salud del individuo y colectividad, el impacto del medio de comunicación en la 
divulgación de los casos y las dificultades de enfrentamiento vividas en los diferentes niveles de atención. Conclusión: la metodología adoptada posibilitó capacitación cualificada de los alumnos para enfrentamiento de la dengue.

Descriptores: Aprendizaje Basada en Problemas; Dengue; Enfermería; Salud Colectiva; Enfermedades Transmisibles.

\section{INTRODUCTION}

Historical transformations in the areas of Education and Health in their political, economic and social contexts have resulted in important changes in Nursing education in Brazil. Since 2001, with the implementation of the National Curricular Guidelines of the Undergraduate Nursing Course (DCN / ENF), the teaching of the profession began to be based on the promotion of meaningful and transformative learning in order to meet the needs of the Single System of Health (SUS) in Brazil ${ }^{(1-3)}$.

In addition, the DCN / ENF encourages the formation of professionals with a generalist, humanistic, critical and reflexive profile capable of recognizing, diagnosing, planning and assisting the individual and the community in the most prevalent health and disease situations according to the national and regional epidemiological profile ${ }^{(3)}$.

Dengue has been prominent in the world scenario among the reemerging diseases that most affect inhabitants of tropical and subtropical countries, especially in the months of October to May, where high temperatures and humidity are frequent, essential conditions for the proliferation of the mosquito Aedes aegypti, its vector ${ }^{(4-5)}$.

According to the World Health Organization, the incidence of dengue has increased 30-fold in the last five decades, with around 50 to 100 million new cases each year ${ }^{(6)}$. Recent data show a global rate of 390 million dengue infections annually, of which 96 million were manifested at any level of clinical severity ${ }^{(7)}$.

In Brazil, the bulletin referring to the 49th epidemiological week reported that in 2016 , there were $1,487,924$ probable cases of dengue in the country, with an incidence rate of 727.6 per 100,000 inhabitants and another 698,745 cases were discarded. Among the Brazilian regions, the Southeast had the highest number of probable records of dengue fever $(57.5 \%)$ and also the highest number of confirmed cases of severe dengue (433 cases) and dengue fever (3,728 cases). In the state of São Paulo, more than 205 thousand new cases were recorded in the year 2016, of which 108 had severe dengue fever and 1,151 dengue cases with warning signs ${ }^{(8)}$.

Considering the current epidemiological situation in Brazil, dengue deserves to be highlighted by the accelerated increase, forming a national epidemic and a serious public health problem, which is an excellent scenario to meet the guidelines established by the DCN / ENF and train competent professionals and engaged in coping with this contemporary epidemic.
With this objective, the educational activity was developed based on the Methodology of Problematization (MP). The MP's option was for its innovative character, using 'problems for the development of learning and teaching, in order to enhance the student's ability to detect and solve real problems and propose solutions ${ }^{\prime(9)}$.

In addition, MP can be used in appropriate situations and related to life and society, in order to prepare the learner to act politically, to understand their reality and to transform it continuously ${ }^{(10)}$.

With the increase in the number of dengue cases throughout Brazil and the circulation of other diseases transmitted by the Aedes aegypti mosquito, including Chikungunya and Zika, it is appropriate to train health professionals, especially nurses, with knowledge and abilities to deal with these diseases and their different impacts on the health of the population, as well as being able to make clinical and managerial decisions that may impact on the endemic and epidemic reality of these diseases.

In this sense, four didactic strategies were used: a dialogical expository class, an active search for possible mosquito breeding centers, a case study and a nursing consultation simulation, which provided reflections and the application of theoretical-practical contents on prevention, control and management clinical practice of dengue cases and practice of epidemiological surveillance (VE).

Thus, the objective of this article is to describe the experience of clinical teaching on dengue and the practice of epidemiological surveillance using MP.

\section{METHOD}

Report of experience on educational activity carried out with students of the 4 th year of the Bachelor of Nursing course of a state university of the city of São Paulo, during the Nursing in Communicable Diseases with a Focus on Collective Health field, in March, 2016. This course has a total workload of 120 hours and aims to develop the capacity to interpret the occurrence and coping of communicable diseases, as well as to provide nursing practices aimed at clinical care (or diseases) and actions of VE.

The educational activity was carried out by three tutors, namely: a teacher, a specialist in a teaching laboratory and a postgraduate student, taking place in the Institution's physical space and in the Nursing Skills Laboratory (LABHABENF) following the synthesized flow in Figure 1.

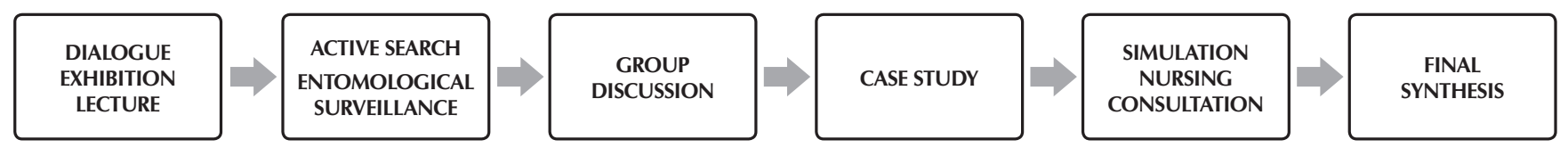

Figure 1 - Flow of practical activities developed in the Institutions and in the Nursing Skills Laboratory, São Paulo, Brazil, 2016 
The dialogue exhibition lecture was given by a lecturer of the Institution and included aspects such as the epidemiological chain of dengue, incidence of disease, pathophysiology and clinical manifestations, diagnosis and treatment, indications of hospitalization and hospital discharge, as well as the need to report cases.

The active and practical search phase of VE, which included the entomological one, had as objective to identify and eliminate possible breeding sites of the Aedes aegypti mosquito, if they were found. It was performed in two groups, for each day of activity, in different places to allow exchanges of experiences in the discussion of groups. The physical space where the activity was developed comprised a three-story building and basement, rooms with balconies and the external area of the Institution. The delimitation of the sites was carried out with the support of the Administrative Technical Assistance team, involving the following sectors: the four departments of education, parking, external and internal garden, roof, foyer, roofs and Academic Center, which were visited at least twice during the course of the discipline.

At the end of the active search, a group discussion was conducted, guided by the question: 'What can the health professional do to avoid the formation of breeding sites for the dengue mosquito?'. The discussions provided the students with a moment of reflection, articulating preventive and EV theory and practices, necessary for the reduction of vector breeding sites, as well as broadening the vision about forms of prevention and control beyond the common sense widely disseminated in the media.

Subsequent activities, case study and simulation of nursing consultation to the individual with dengue, were made possible in four LABHABENF clinics, which were previously equipped with: stethoscope, sphygmomanometer, care flow chart, notification card, dengue card, prescriptions and informative manuals.

Four different cases of dengue patients, which varied according to complexity, were presented to the students to allow classification of the staging: the first, by a 44-year-old man with classic dengue symptoms; the second was about a 15-week-old pregnant teenager; the third approach was a 50-year-old woman with chronic metabolic disease, who returned to the Basic Health Unit for new care with warning signs; and the fourth was referring to a 47-year-old man who came to the health unit with warning signs four days after the onset of symptoms.

It is worth noting that for all cases, information on living and living conditions was included in different socioeconomic scenarios, which could favor the creation or existence of dengue vectors, such as accumulation of residues and other materials in backyards, water at ground level, open water box, swimming pool or bathroom in disuse, among others.

The clinical simulation of the nursing consultation to attend dengue cases was performed as follows: each pair of students received a case for care, one student playing the role of nurse and the other as a user. The student 'nurse' received a copy of the case with brief information about the person to be served, such as name, age, main complaint and the task that should be performed. The student who would represent the user received the complete case, with information about the location of the residence, symptoms, temperature and photo record with the positive or negative bond proof, depending on the case to be analyzed; was also instructed to provide the information to the extent that the student 'nurse' requested. Both had 30 minutes to prepare for service and clarify any doubts; the duration of care should not exceed 90 minutes.

Before carrying out the simulated consultation, all the students attended an educational video about the tie test, which showed how it should be performed in adults and children, as well as their need and importance during care in suspected cases of dengue. During the nursing consultation, the students were able to practice anamnesis and directed physical examination, and were even instructed to perform the tie test.

The tie test must be performed in the screening, in all patients with suspected dengue and who do not present spontaneous bleeding. Its purpose is to determine the fragility of the capillary walls and help in the recognition of vascular alterations ${ }^{(11)}$.

For each case, the students should carry out an analysis of the socioeconomic situation and the way of life, in order to reconstruct the form of transmission of the disease following the epidemiological reasoning and to relate with the data that appeared in the compulsory notification form.

The tutors had a form with the activities expected to facilitate the final synthesis, which included classification of the case according to the Ministry of Health flow chart and questions related to user identification, symptoms and clinical evaluation, case notification, delivery of the card of dengue for the user and information about the residence of the person of the analyzed case. During the activity, the tutors were close to the rooms to intervene, if necessary.

At the end of the simulation, everyone participated in the final synthesis, guided by the following questions, 'In your view, what was lacking in order to better serve the case?', 'Which highlights would you point out during your evaluation of the clinical case of dengue?', 'What did you learn from this activity?'.

\section{RESULTS}

During the dialogic expository lecture, students and teachers rescued previous knowledge about the disease and were able to discuss the need to expand prevention and health promotion actions in the individual, home and collective settings. It was also possible to discuss the impact of the media in the dissemination of cases, the difficulties faced by this epidemic experienced in the different levels of attention and other aspects that favored the construction of theoretical knowledge.

The active and practical search of VE showed to be a motivating activity that aroused in the students the curiosity and the feeling of empowerment, since they were allowed to survey and evaluate different environments of the Institution, not always with habitual access. In the surveys were possible to find mosquitoes breeding sites and centers, and the tutors encouraged the students to photograph them to share with other colleagues during the discussion, as well as eliminate them whenever possible.

Various materials were collected, such as plastic bottles, disposable cups, various plastics, and when water was placed in potted plants, the students discarded it, cleaned the compartment and positioned it in a way that no longer accumulated 
water. In the parking lot, a great number of bromeliads were found, plants that accumulate water, which proved to be a very interesting experience, which broadened students' view of the need to seek alternative means of control, without necessarily eliminating landscape vegetation.

Professionals responsible for maintaining the Institution's facilities accompanied the students in some activities and were able to clarify the routine care carried out, for example, the removal of garbage in the areas adjacent to the sidewalks, pruning of the grass and the treatment of bromeliads, according to the guidance of competent bodies.

Those in charge of the administrative technical sector were informed about the progress of the activities and took action when possible mosquitoes were spotted. It is important to note that, in none of these sites, larvae were found, but water stopped, with risk of mosquito breeding.

The case study and the simulation of the nursing consultation for dengue care enabled the development of students' abilities, attitudes and knowledge regarding the care of users with dengue, as well as providing reflections and exercise of clinical reasoning, valuation of epidemiological reality, 'loopproof' procedure and classification of the severity of the case.

During the final synthesis, questions emerged about the importance of notification of dengue cases, difficulty in classifying them, different forms of awareness of the population, experience as a professional and user, the latter being considered by the students as a differential, since alerted to the need to value the social context of the user as an important condition for his illness.

All students completed the compulsory notification form and discussed their importance for the maintenance of health activities. Some pointed out that the best time to perform this procedure would be during the consultation with the user, for facilitating data collection and subsequent monitoring and investigation. It is worth mentioning that, during the course of the course, students carry out internships in Regional Vigilance Centers of the municipality, which allows the connection between knowledge and practices and broadens the vision about the importance of the VE.

\section{DISCUSSION}

The educational activity reported provided the problematization of the practice of VE through the active search for Aedes aegypti outbreaks and breeding grounds, as well as the development of skills to perform the nursing consultation for suspected cases of dengue, through simulated practice.

The discussion of the active search activity was mainly based on the role of the nurse to control dengue, considering the mosquito cycle, mode of transmission, incubation period and transmissibility of the disease, and in the actions of EV and entomological.

The active search strategy should be incorporated into nurses' daily routine, since it allows the development of epidemiological research actions that favor not only the collection of data and assistance to the individuals affected by the disease, but also the articulation of knowledge and practices that privilege families and social groups in the context of the social determination of the disease health process ${ }^{(11)}$.

This moment can be considered decisive to adopt measures capable of preventing future epidemics, such as: social mobilization and education of the population, encouraging self-care of the user, care of the residence and community, monitoring of cases through home visits, updating of consistent information systems and intersectoral actions in the territory, privileging the interlocution between the Family Health Strategy team and Sanitary and Epidemiological Surveillance ${ }^{(12)}$.

Regarding the notification forms, the study analyzed the completeness of the fields of the individual records and demonstrated the need for investments in the training of professionals, in order to raise awareness about the importance and responsibility of compulsory notification of diseases, in order to allow managers and professionals a reliable diagnosis of the health needs of the population ${ }^{(13)}$.

The action of detection and control of the Aedes aegypti mosquito carried out through the active search and the filling of the compulsory notification form in the simulated consultation contributed to the students' training, leading them to reflect on the fundamental contribution of the VE practices to the confrontation of dengue fever, especially with regard to vector-fighting actions, and the importance of correct and complete reporting forms.

The reinforcement of clinical and epidemiological management actions should be encouraged, since some students reported that in previous experiences they did not see this participation of the nurse in preventive activities, which was justified by the professionals as overload of work overlapping the administrative demand and bureaucracy of the health unit.

The recognition of the fundamental role of nurses in the development of actions aimed at the promotion, prevention and control of dengue in the SUS context, considering the individual, family and society, is of great relevance for undergraduates, as it highlights the importance of their participation.

The simulation can be considered a valuable contribution to the traditional model of Nursing teaching ${ }^{(14)}$, since it involves different techniques and procedures, such as games, anatomical models, mannequins with different degrees of fidelity, case studies, simulated patient, role playing and presentation of multimedia $^{(15)}$. A Brazilian study indicates that educational activities based on simulated conditions are contributing to the practical training of Nursing students, especially in the transition from the controlled laboratory to clinical care ${ }^{(16)}$.

At present, to institute activities that simulate a real situation in the professional formation, especially in Nursing, means to consider the problematizing approach as a component that favors the construction of knowledge, attending to the need to train citizens who are increasingly critical, reflexive and versatile $^{(17-18)}$, that act in diverse realities.

The simulated practice provides students with a controlled reality and enables the development of different professional skills, making them able to deal with everyday work situations. In addition, it favors overcoming problems such as anxiety, stress and fear of making mistakes, among others, generated during the beginning of traditional teaching practice activities. 
The group of students considered this activity important and enriching for learning, because in the evaluation of the discipline, $78 \%$ of them reported having facilitated the understanding and reinforced the content delivered in the classroom.

\section{Limitations of the study}

The limitations are related to the fact that the educational activity was tested only once, for undergraduate students in Nursing at a public university.

Contributions to the area of nursing, health or public policy

The contribution of this report is related to the innovative potential of the educational activity and the possibility of replication in different academic and epidemiological contexts, for different communicable diseases.

\section{CONCLUSION}

Describing the experience of teaching about dengue and VE practice, using MP, showed its potential for the development of Nursing students' abilities for care in dengue cases.

Although this teaching strategy was adopted for the first time in the subject Nursing in Communicable Diseases with a Focus on Collective Health, it has proved to be an important educational resource, especially in situations in which there is a need to strengthen knowledge so that it is absorbed quickly and safely of epidemic conditions, such as the one we are currently living in: an epidemic of dengue.

The participation of students in doctoral and master's degree programs in the School Improvement Program was of great value, both in the elaboration and execution of this strategy. The involvement of undergraduate students in undergraduate teaching activities favors training for teaching with a careful look at the daily challenges of health professionals.

It is also worth noting the involvement of the Institution's employees who, when they perceived the movement of the students in the search for breeding places, raised pertinent questions and contributed by pointing out places that should be inspected. Thus, this activity also enabled the employees to recognize their importance in the conservation of a safer environment regarding the transmission of dengue.

The adoption of this teaching strategy proved to have achieved its purpose, since the evaluation of the students at the end of the activity was positive, and there is a suggestion to extend it to other situations that are part of the discipline program.

\section{ACKNOWLEDGMENT}

To the professionals of the Administrative Technical Assistance Team of the Institution.

\section{REFERENCES}

1. Ito EE, Peres AM, Takahashi RT, Leite MMJ. O ensino de enfermagem e as diretrizes curriculares nacionais: utopia $\mathrm{x}$ realidade. Rev Esc Enferm USP [Internet]. 2006 [cited 2016 Aug 02];40(4):570-5. Available from: http://www.scielo.br/pdf/reeusp/v40n4/ v40n4a16.pdf

2. Fernandes JD, Xavier IM, Ceribelli MIPF, Bianco MHC, Maeda D, Rodrigues MVC. Diretrizes curriculares e estratégias para implantação de uma nova proposta pedagógica. Rev Esc Enferm USP [Internet]. 2005 [cited 2016 Aug 02];39(4):443-9. Available from: http://www.ee.usp.br/reeusp/upload/pdf/66.pdf

3. Brasil. Ministério da Educação. Conselho Nacional de Educação. Câmara de Educação Superior. Resolução CNE/CES nº 3 de 7 de novembro de 2001. Institui Diretrizes Curriculares Nacionais do Curso de Graduação em Enfermagem [Internet]. Diário Oficial da União, Brasília, 09 Nov. 2001. Seção 01. 2001 [cited 2016 Apr 4]. Available from: http://portal.mec.gov.br/cne/arquivos/pdf/ CES03.pdf

4. Brasil. Ministério da Saúde. Secretaria de Vigilância em Saúde. Departamento de Vigilância das Doenças Transmissíveis. Plano de Contingência Nacional para Epidemias de Dengue [Internet]. Brasília: Ministério da Saúde, 2015 [cited 2016 Apr 4]. Available from: http://www.cve.saude.sp.gov.br/htm/zoo/pdf/ms15_plano-contingencia-dengue-19jan15.pdf

5. Dias LBA, Almeida SCL, Haes TM, Mota LM, Roriz-Filho JS. Dengue: transmissão, aspectos clínicos, diagnóstico e tratamento. Med Ribeirão Preto [Internet]. 2010 [cited 2016 Apr 17];3(2):143-52. Available from: http://revista.fmrp.usp.br/2010/vol43n2/ Simp6_Dengue.pdf

6. World Health Organization (WHO). Global strategy for dengue prevention and control 2012-2020 [Internet]. Geneva: WHO Library, 2012 [cited 2016 Apr 4]. Available from: http://apps.who.int/iris/bitstream/10665/75303/1/9789241504034_eng.pdf

7. Bhatt S, Gething PW, Brady OJ, Messina JP, Farlow AW, Moyes CL, et al. The global distribution and burden of dengue. Nature [Internet]. 2013 [cited 2016 Apr 17];496(7446):504-7. Available from: http://www.nature.com/nature/journal/v496/n7446/full/ nature12060.html

8. Brasil. Ministério da Saúde. Secretaria de Vigilância em Saúde. Boletim epidemiológico [Internet]. 2016[cited 2016 Apr 4];47(38):110. Available from: http://portalarquivos.saude.gov.br/images/pdf/2016/dezembro/20/2016-033---Dengue-SE49-publicacao.pdf

9. Silva JPV, Tavares CMM. Integralidade: dispositivo para a formação crítica dos profissionais de Saúde. Trab Educ Saúde [Internet]. 2004 [cited 2016 Aug 02];2(2):271-85. Available from: http://www.scielo.br/pdf/tes/v2n2/04.pdf

10. Berbel NAN. A problematização e a aprendizagem baseada em problemas: diferentes termos ou diferentes caminhos? 
Interface[Internet]. 1998 [cited 2016 Aug 02];2(2):139-54. Available from: 10.1590/S1414-32831998000100008

11. Nichiata LYI, Borges ALV, Zoboli ELCP. Enfermagem em saúde coletiva: o diagrama de controle como estratégia de ensino de vigilância epidemiológica das doenças transmissíveis. Rev Min Enferm [Internet]. 2005 [cited 2016 Aug 02];9(4):367-70. Available from: http://www.reme.org.br/artigo/detalhes/486

12. Brasil. Ministério da Saúde. Dengue: manual de enfermagem. 2.ed. Brasília: Ministério da Saúde, 2013. Internet [cited 2016 Aug 02]. Available from: http://bvsms.saude.gov.br/bvs/publicacoes/dengue_manual_enfermagem.pdf

13. Barreto PA, Braga ALS, Andrade M. Avaliação da completitude dos registros de dengue: estudo exploratório de notificações compulsórias. Online Braz J Nurs[Internet]. 2012 [cited 2016 Aug 02];11(3). Available from: http://www.objnursing.uff.br/index. php/nursing/rt/printerFriendly/3920/1881

14. Duphily NH. Simulation education: a primer for professionalism. Teaching and learning in nursing [Internet]. 2014 [cited 2016 Aug 02];9(3):126-9. Available from: http://dx.doi.org/:10.1016/j.teln.2014.03.003

15. Tuoriniemi $P$, Schott-Baer D. Implementing a high-fidelity simulation program in a community college setting. Nurs Educ Perspect[Internet]. 2008 [cited 2016 Aug 02];29(2):105-9. Available from: http://journals.Iww.com/neponline/Fulltext/2008/03000/ IMPLEMENTING_a_High_Fidelity_Simulation_Program_in.12.aspx

16. Teixeira INAO, Felix JVC. Simulação como estratégia de ensino em enfermagem: revisão de literatura. Interface [Internet]. 2011 [cited 2016 Aug 02];15(39):1173-84. Available from: http://www.scielo.br/pdf/icse/v15n39/aop3011.pdf

17. Medeiros SB, Pereira CDFD, Tourinho FSV, Fernandes LGG, Santos VEP. Exame clínico objetivo estruturado: reflexões sob um olhar da enfermagem. Cogitare Enferm [Internet]. 2014 [cited 2016 Aug 02];19(1):170-3. Available from: http://ojs.c3sl.ufpr.br/ ojs/index.php/cogitare/article/view/35977

18. Galato D, Alano GM, França TF, Vieira AC. Exame clínico objetivo estruturado (ECOE): uma experiência de ensino por meio de simulação do atendimento farmacêutico. Interface[Internet]. 2011 [cited 2016 Aug 02];15(36):309-19. Available from: http:// dx.doi.org/10.1590/S1414-32832010005000032 